\title{
Phenolic Constituents with Antioxidative, Tyrosinase Inhibitory and Anti-aging Activities from Dendrobium loddigesii Rolfe
}

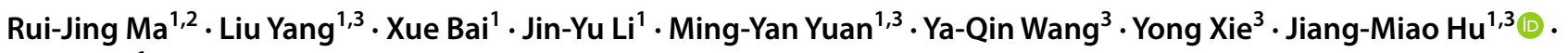 \\ Jun Zhou ${ }^{1}$
}

Received: 10 June 2019 / Accepted: 15 September 2019 / Published online: 19 October 2019

(c) The Author(s) 2019

\begin{abstract}
Aqueous ethanol extracts of powdered stems of Dendrobium loddigesii afforded three new phenolics including threo-7-Oethyl-9-O-(4-hydroxyphenyl)propionyl-guaiacylglycerol (1), $(R)$-4,5,4'-trihydroxy-3,3', $\alpha$-trimethoxybibenzyl (2) and $(S)$ 5,5',7-trihydroxy-3',4'-dimethoxyflavanone (3), together with eleven known analogues. Their structures were determined by extensive spectroscopic analysis. To identify natural antioxidants, whitening, and anti-aging agents, the abilities of these phenolics were assessed to scavenge the 1,2-diphenyl-2-picrylhydrazyl (DPPH) radical, their abilities to inhibit tyrosinase production, and their abilities to stimulate collagen production by human dermal fibroblasts-adult (HDFa) assay. It was found that compounds 1, 4-8,13 and 14 exhibited significant DPPH radical scavenging activities, compound 10 exhibited tyrosinase inhibitory activity $\left(\mathrm{IC}_{50} 37.904 \mu \mathrm{g} / \mathrm{mL}\right.$ ), and compound $\mathbf{9}$ showed significant collagen production with an $\mathrm{EC}_{50}$ value of $3.182 \mu \mathrm{g} / \mathrm{mL}$. These results suggest that phenolic constituents from $D$. loddigesii may be candidate antioxidants, skin-whitening and/or anti-aging agents.
\end{abstract}

\section{Graphic Abstract}

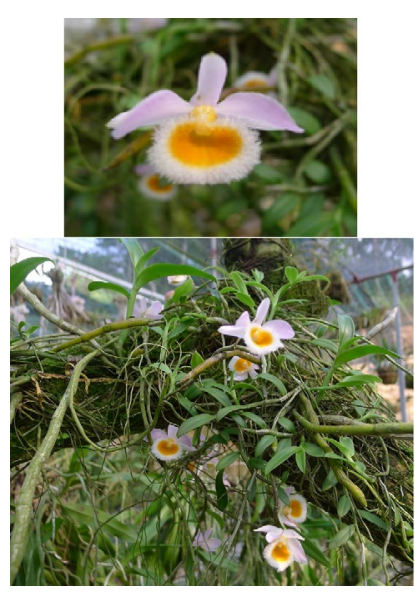

Dendrobium loddigesii Rolfe

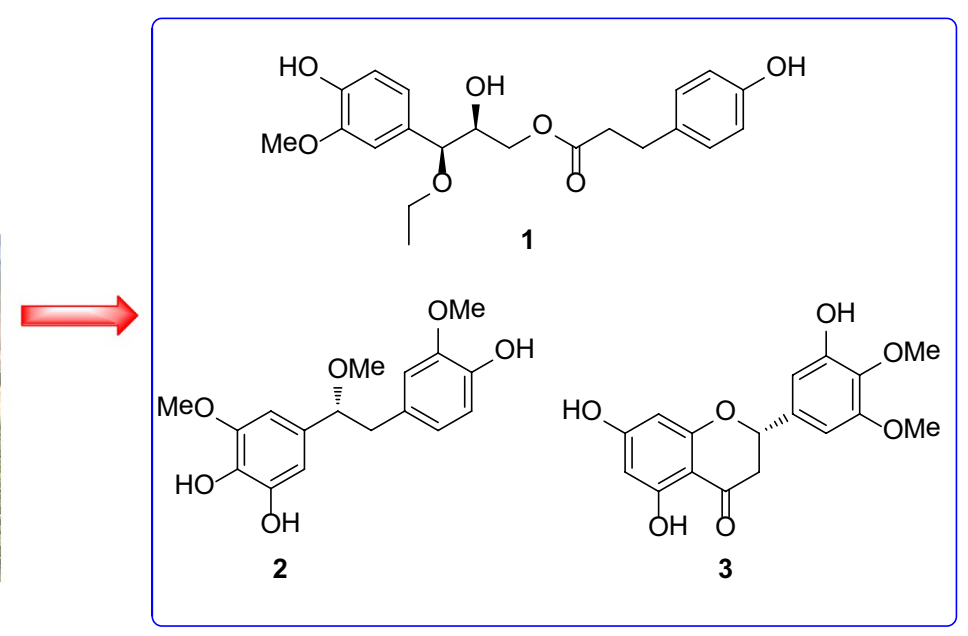

Keywords Dendrobium loddigesii $\cdot$ Phenolic constituents $\cdot$ Antioxidative $\cdot$ Tyrosinase inhibitory $\cdot$ Anti-aging

Rui-Jing Ma and Liu Yang have contribute equally to this work.

Electronic supplementary material The online version of this article (https://doi.org/10.1007/s13659-019-00219-y) contains supplementary material, which is available to authorized users.

Extended author information available on the last page of the article

\section{Introduction}

The genus Dendrobium (Orchidaceae) contains approximately 1500 species globally, of which about 80 species grow in China [1]. The stems of several plants in this genus 


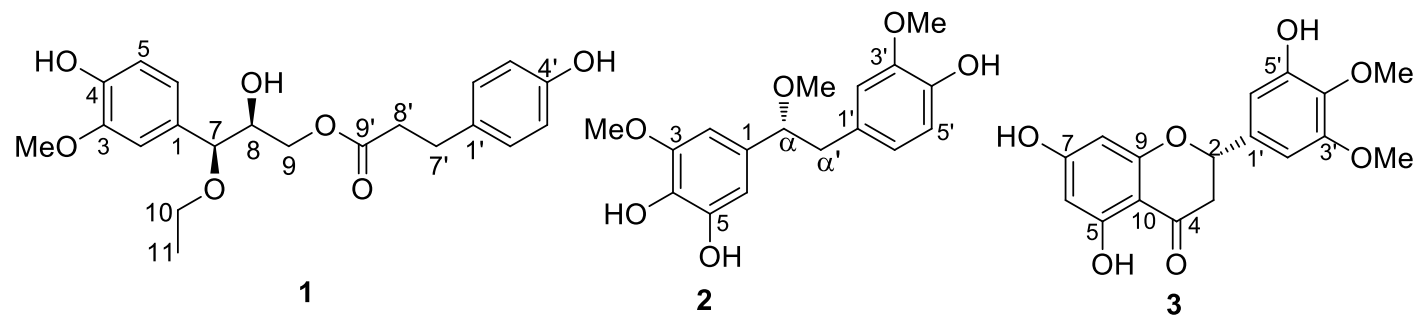<smiles>[R]c1cc(CCc2ccc(O)c(OC)c2)cc([R3])c1[R2]</smiles>

$\begin{array}{llll} & \mathrm{R}_{1} & \mathrm{R}_{2} & \mathrm{R}_{3} \\ 4 & \mathrm{OMe} & \mathrm{OMe} & \mathrm{OMe} \\ \mathbf{5} & \mathrm{OMe} & \mathrm{OH} & \mathrm{OMe} \\ \mathbf{6} & \mathrm{OMe} & \mathrm{OH} & \mathrm{OH} \\ \mathbf{7} & \mathrm{OMe} & \mathrm{H} & \mathrm{OH} \\ \mathbf{8} & \mathrm{OH} & \mathrm{H} & \mathrm{OH}\end{array}$<smiles>COc1cc(CCCOC(=O)CCc2ccc(O)cc2)ccc1O</smiles>

13<smiles>[R]c1cc(O)cc(CCc2cccc(O)c2)c1</smiles>

$9 \mathrm{R}=\mathrm{OMe}$<smiles>[R]c1cc(O)cc(CCc2ccc3c(c2)OCO3)c1</smiles>

$11 \mathrm{R}=\mathrm{OH}$

$12 \mathrm{R}=\mathrm{OMe}$

Fig. 1 Chemical structures of compounds 1-14

are known as "Shi-Hu", which have been used for thousands of years as both traditional Chinese medicine and folk remedies for the treatment chronic atrophic gastritis, skin aging, fever, cardiovascular disease and a tonic for promoting the production of body fluid [2]. Previous studies on this genus led to the isolation of a series of polysaccharides, phenolic compounds, alkaloids, and sesquiterpenoids [1, 3-5], some of which possess various bioactivities including anti-inflammatory [6], antimicrobial [2], antioxidant [7], antitumor [8], antiplatelet aggregation [9], immunomodulatory [10], and against influenza A activities [11].

Dendrobium loddigesii, a perennial epiphytic herb, is widely distributed in the southwestern area of China, such as Guangxi, Guizhou, and Yunnan Provinces [12]. Its stem has been applied in folk medicine to treat gastrosis, fever, and dizziness [13]. In continuing the search for structurally diverse and biologically active natural products from this genus [1, 5, 14-17], an in-depth investigation of pharmacologically active constituents from this plant species was performed herein. As a result, three new phenolic compounds (1-3) as well as eleven known ones (Fig. 1) were isolated from an $80 \%$ ethanolic extract of the stem of D. loddigesii. The isolation, structure elucidation, and biological evaluation of these compounds are presented herein.

\section{Results and Discussion}

Compound 1, obtained as white solid, gave a molecular formula of $\mathrm{C}_{21} \mathrm{H}_{26} \mathrm{O}_{7}$ as determined by the (-)-HRESIMS ion at $\mathrm{m} / \mathrm{z} 389.1602[\mathrm{M}-\mathrm{H}]^{-}$(calcd for $\mathrm{C}_{21} \mathrm{H}_{25} \mathrm{O}_{7}$, 389.1606) with nine degrees of unsaturation. The ${ }^{1} \mathrm{H}$ NMR spectrum of 1 contains seven aromatic protons at $\delta_{\mathrm{H}} 6.85(1 \mathrm{H}, \mathrm{d}, J=1.7 \mathrm{~Hz}), 6.75(1 \mathrm{H}, \mathrm{d}, J=8.0 \mathrm{~Hz}), 6.68$ $(1 \mathrm{H}, \mathrm{dd}, J=8.0,1.7 \mathrm{~Hz}), 7.01(2 \mathrm{H}, \mathrm{d}, J=8.5 \mathrm{~Hz})$ and $6.68(2 \mathrm{H}, \mathrm{d}, J=8.5 \mathrm{~Hz})$, suggesting the presence of a 1,3,4-trisubstituted benzene ring and a 1,4-disubstituted benzene ring. Its ${ }^{13} \mathrm{C}$ NMR spectrum exhibited 21 carbon resonances including two methyl (one methoxy), four aliphatic methylene, nine methine (two $s p^{3}$, seven $s p^{2}$ ), and six quaternary carbons (one carbonyl, five olefinic including three oxygenated). The HMBC correlations (Fig. 2) of H-7/C-1 $\left(\delta_{\mathrm{C}} 131.6\right), \mathrm{C}-2\left(\delta_{\mathrm{C}} 111.7\right), \mathrm{C}-6\left(\delta_{\mathrm{C}} 121.4\right)$, $\mathrm{C}-8\left(\delta_{\mathrm{C}} 74.2\right)$ and $\mathrm{C}-10\left(\delta_{\mathrm{C}} 65.3\right)$; H-9/C-7 $\left(\delta_{\mathrm{C}} 83.8\right)$ and C-8 $\left(\delta_{\mathrm{C}} 74.2\right) ; \mathrm{H}-10 / \mathrm{C}-11\left(\delta_{\mathrm{C}} 15.6\right)$; 3-OMe $\left(\delta_{\mathrm{H}} 3.81\right) / \mathrm{C}-3$ $\left(\delta_{\mathrm{C}} 149.1\right)$, together with correlations of $\mathrm{H}-7 / \mathrm{H}-8 / \mathrm{H}_{2}-9$ and $\mathrm{H}_{2}-10 / \mathrm{H}_{3}-11$ from ${ }^{1} \mathrm{H}-{ }^{1} \mathrm{H}$ COSY spectrum (Fig. 2) indicated the presence of 7-O-ethylguaiacylglycerol [18]. It has been reported that $J_{7,8}$ was about $5 \mathrm{~Hz}$ for the 


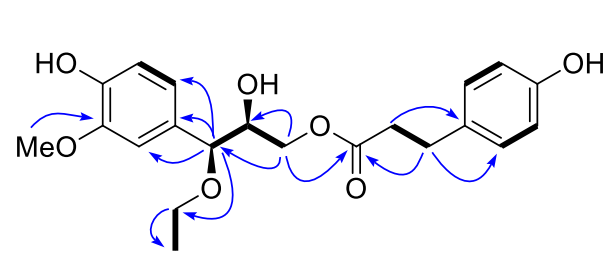

1

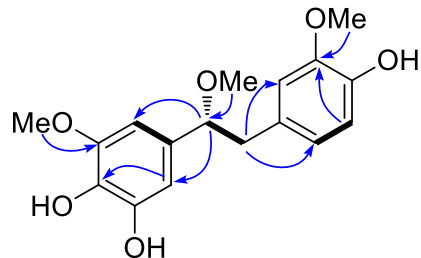

2

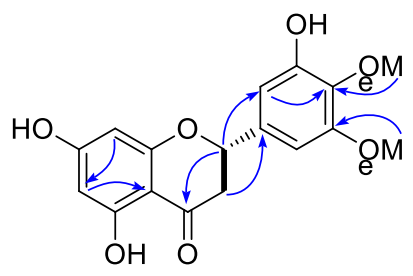

3

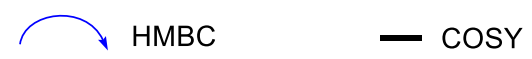

Fig. 2 The key HMBC and COSY correlations of compounds 1-3

erythro isomer and $7 \mathrm{~Hz}$ for the threo isomer in the cases of syringoyl-glycerols and guaiacylglycerol derivatives. Thus, compound $\mathbf{1}$ was considered to be the threo isomer with $J_{7,8}(6.5 \mathrm{~Hz})$ [18]. The HMBC correlations of H-7' $\left(\delta_{\mathrm{H}} 2.79, \mathrm{t}, J=7.5 \mathrm{~Hz}\right) / \mathrm{C}-8^{\prime}\left(\delta_{\mathrm{C}} 37.1\right), \mathrm{C}-1^{\prime}\left(\delta_{\mathrm{C}} 132.7\right)$, $\mathrm{C}-2^{\prime}, 6^{\prime}\left(\delta_{\mathrm{C}} 130.2\right)$ and $\mathrm{C}-9^{\prime}\left(\delta_{\mathrm{C}} 174.6\right), \mathrm{H}-8^{\prime}\left(\delta_{\mathrm{H}} 2.59\right.$, $\mathrm{t}, J=7.5 \mathrm{~Hz}) / \mathrm{C}-7^{\prime}\left(\delta_{\mathrm{C}} 31.0\right), \mathrm{C}-1^{\prime}$, and C-9', along with COSY cross-peaks of $\mathrm{H}-8^{\prime} / \mathrm{H}-7^{\prime}$ indicated the presence of $p$-hydroxycoumaric acid [19]. On the basis of the evidences described above, 1 was proposed to have a 7-O-ethylguaiacylglycerol moiety and a $p$-hydroxycoumaric acid via an ester linkage. The HMBC correlation from $\mathrm{H}-9$ to C-9' suggested the ester linkage was between C-9 and C-9'. Thus, the structure of $\mathbf{1}$ was determined as shown.

$(R)-4,5,4^{\prime}$-Trihydroxy-3,3', $\alpha$-trimethoxybibenzyl (2) was obtained as white solid. The HRESIMS spectrum of 2 displayed a quasimolecular ion peak at $\mathrm{m} / \mathrm{z} 319.1180$ $[\mathrm{M}-\mathrm{H}]^{-}$(calcd. for $\mathrm{C}_{17} \mathrm{H}_{19} \mathrm{O}_{6}, 319.1187$ ) with 8 degrees of unsaturation. The ${ }^{1} \mathrm{H}$ NMR spectrum of $\mathbf{2}$ showed three methoxyl groups at $\delta_{\mathrm{H}} 3.75(3 \mathrm{H}, \mathrm{s}), 3.70(3 \mathrm{H}, \mathrm{s})$ and 3.17 $(3 \mathrm{H}, \mathrm{s})$; one oxygenated methine proton at $\delta_{\mathrm{H}} 4.13(1 \mathrm{H}, \mathrm{t}$, $J=6.8 \mathrm{~Hz}, \mathrm{H}-\alpha)$; two methylene signals at $\delta_{\mathrm{H}} 2.73(1 \mathrm{H}, \mathrm{dd}$, $J=13.5,6.9 \mathrm{~Hz})$ and $2.96(1 \mathrm{H}, \mathrm{dd}, J=13.5,6.9 \mathrm{~Hz})$; and five aromatic protons, appearing as a 1,3,4,5-tetrasubstituted aromatic ring at $\delta_{\mathrm{H}} 6.28(1 \mathrm{H}, \mathrm{d}, J=1.8 \mathrm{~Hz})$ and 6.34 $(1 \mathrm{H}, \mathrm{d}, J=1.8 \mathrm{~Hz})$, and a 1,3,4-trisubstituted aromatic ring at $\delta_{\mathrm{H}} 6.49(1 \mathrm{H}, \mathrm{d}, J=2.0 \mathrm{~Hz}), 6.62(1 \mathrm{H}, \mathrm{d}, J=8.0 \mathrm{~Hz})$ and $6.52(1 \mathrm{H}, \mathrm{dd}, J=8.0,2.0 \mathrm{~Hz})$. The ${ }^{13} \mathrm{CNMR}$ and DEPT spectra of 2 showed three oxymethyls, one methylene, one oxygenated methine and 12 aromatic carbons (five oxygenated). Comparison of its NMR data (Table 1) with those of dendrocandin C [20] showed great similarities except for the presence of one more methoxyl group, which was located at $\mathrm{C}-3^{\prime}$ by the HMBC correlations from $3^{\prime}$-OMe and $\mathrm{H}-5^{\prime}$ to $\mathrm{C}-3^{\prime}\left(\delta_{\mathrm{C}} 148.4\right)$. In addition, the multiple $\mathrm{HMBC}$ interactions (Fig. 2) of 3-OMe and H-2/C-3 $\left(\delta_{\mathrm{C}}\right.$ $149.5) ; \alpha-\mathrm{OMe} / \mathrm{C}-\alpha\left(\delta_{\mathrm{C}} 86.9\right)$ suggested the other methoxyl groups at $\mathrm{C}-3$, and $\mathrm{C}-\alpha$, respectively. The absolute configuration at $\mathrm{C}-\alpha$ was determined as $R$ on the basis of the negative optical rotation $\left([\alpha]_{D}^{26}-12.46\right)$, similar to aphyllal
$\left.\mathrm{D}[\alpha]_{\mathrm{D}}^{20}-20.3, \mathrm{MeOH}\right)[15]$. Accordingly, the structure of 2 was determined as shown.

(S)-5,7,5'-Trihydroxy-3',4'-dimethoxyflavanone (3) was obtained as yellow amorphous powder and had the molecular $\mathrm{C}_{17} \mathrm{H}_{16} \mathrm{O}_{7}$ (10 indices of hydrogen deficiency) according to the (-)-HRESIMS ion at $\mathrm{m} / \mathrm{z} 331.0819[\mathrm{M}-\mathrm{H}]^{-}$(calcd 331.0823). The UV absorption maxima at 206 and $294 \mathrm{~nm}$ indicated the presence of a flavanone [21]. The ${ }^{1} \mathrm{H}$ NMR spectrum (Table 1) showed three signals in non-aromatic region placed at $\delta_{\mathrm{H}} 5.29(1 \mathrm{H}, \mathrm{dd}, J=12.7,3.1, \mathrm{H}-2), 3.04$ $(1 \mathrm{H}, \mathrm{dd}, J=17.1,12.7, \mathrm{H}-3 \mathrm{ax})$, and $2.71(1 \mathrm{H}, \mathrm{dd}, J=17.1$, $3.1, \mathrm{H}-3 \mathrm{eq})$, four aromatic protons $\delta_{\mathrm{H}} 5.87(1 \mathrm{H}, \mathrm{d}, J=2.2$, H-6), 5.91 (1H, d, $J=2.2, \mathrm{H}-8), 6.62$ (1H, d, $\left.J=2.0, \mathrm{H}-2^{\prime}\right)$ and $6.61\left(1 \mathrm{H}, \mathrm{d}, J=2.0, \mathrm{H}-6^{\prime}\right)$, two methoxyl groups $\delta_{\mathrm{H}} 3.83$ $(3 \mathrm{H}, \mathrm{s})$ and $3.77(3 \mathrm{H}, \mathrm{s})$. The ${ }^{13} \mathrm{C}$ NMR and DEPT spectra (Table 1) contain resonances for 17 carbons including one two methoxy, one methylene, one methine, one carbonyl carbon and 12 aromatic carbons. Comprehensive analysis of its NMR data indicated that its planar structure is closely related with that of dihydrotricin [22], except for the $\mathrm{OH}-4^{\prime}$ and $\mathrm{OCH}_{3}-5^{\prime}$ resonances in dihydrotricin were transposed in 3. This was confirmed by the HMBC cross-peaks (Fig. 2) from $\mathrm{H}-2^{\prime}, \mathrm{H}-6^{\prime}$ and $\mathrm{OCH}_{3}-4^{\prime}$ to $\mathrm{C}-4^{\prime}\left(\delta_{\mathrm{C}} 137.7\right)$, from H-6' to $\mathrm{C}-5^{\prime}\left(\delta_{\mathrm{C}} 151.8\right)$. The absolute configuration at $\mathrm{C}-2$ was postulated as being in the $S$-form on the basis of a negative specific rotation value $(-46.64, \mathrm{MeOH})$ in its optical rotation [23]. Therefore, the structure of compound $\mathbf{3}$ was thus unambiguously assigned as shown.

Eleven known compounds were identified to be crepidatin 4 [24], moscatilin 5 [25], 4,5,4'-trihydroxy3,3'-dimethoxybibenzyl 6 [26], 4',5-dihydroxy-3,3'dimethoxybibenzyl 7 [27], tristin 8 [28], batatasin III 9 [27], 3,5,3'-hydroxybibenzyl 10 [29], aphyllals C 11 [15], densiflorol A 12 [30], dihydroconiferyl dihydro- $p$-coumarate 13 [31], $p$-hydroxyphenethyl trans-ferulate 14 [32] by spectroscopic analysis and comparing their spectral data with literature.

Phenolic compounds, are an essential part of the human diet and are known as powerful antioxidants due to their 
Table 1 The ${ }^{1} \mathrm{H}$ and ${ }^{13} \mathrm{C}-\mathrm{NMR}$ data of $\mathbf{1 - 3}$ (methanol- $d_{4}, \delta$ in ppm, $J$ in $\mathrm{Hz}$ )

\begin{tabular}{|c|c|c|c|c|c|c|c|c|}
\hline \multirow[t]{2}{*}{ No. } & \multicolumn{2}{|l|}{$1^{\mathrm{a}}$} & \multirow[t]{2}{*}{ No. } & \multicolumn{2}{|l|}{$2^{b}$} & \multirow[t]{2}{*}{ No. } & \multicolumn{2}{|l|}{$3^{\mathrm{b}}$} \\
\hline & $\delta_{\mathrm{H}}$ & $\delta_{\mathrm{C}}$ & & $\delta_{\mathrm{H}}$ & $\delta_{\mathrm{C}}$ & & $\delta_{\mathrm{H}}$ & $\delta_{\mathrm{C}}$ \\
\hline 1 & & $131.6 \mathrm{~s}$ & 1 & & $134.6 \mathrm{~s}$ & 1 & & \\
\hline 2 & $6.85 \mathrm{~d}(1.7)$ & $111.7 \mathrm{~d}$ & 2 & $6.28 \mathrm{~d}(1.8)$ & $103.4 \mathrm{~d}$ & 2 & $5.29 \mathrm{dd}(12.7,3.1)$ & $80.4 \mathrm{~d}$ \\
\hline 3 & & $149.1 \mathrm{~s}$ & 3 & & $149.5 \mathrm{~s}$ & 3 & $\begin{array}{l}3.04 \mathrm{dd}(17.1,12.7) \\
2.71 \mathrm{dd}(17.1,3.1)\end{array}$ & $44.2 \mathrm{t}$ \\
\hline 4 & & $147.5 \mathrm{~s}$ & 4 & & $133.4 \mathrm{~s}$ & 4 & & $197.4 \mathrm{~s}$ \\
\hline 5 & $6.75 \mathrm{~d}(8.0)$ & $116.0 \mathrm{~d}$ & 5 & & $146.5 \mathrm{~s}$ & 5 & & $165.4 \mathrm{~s}$ \\
\hline 6 & $6.68 \mathrm{dd}(8.0,1.7)$ & $121.4 \mathrm{~d}$ & 6 & $6.34 \mathrm{~d}(1.8)$ & $108.6 \mathrm{~d}$ & 6 & $5.87 \mathrm{~d}(2.2)$ & $97.1 \mathrm{~d}$ \\
\hline 7 & $4.14 \mathrm{~d}(6.5)$ & $83.8 \mathrm{~d}$ & $1^{\prime}$ & & $131.1 \mathrm{~s}$ & 7 & & 168.4 \\
\hline 8 & $3.82 \mathrm{~m}$ & $74.2 \mathrm{~d}$ & $2^{\prime}$ & $6.49 \mathrm{~d}(2.0)$ & $114.4 \mathrm{~d}$ & 8 & $5.91 \mathrm{~d}(2.2)$ & $96.2 \mathrm{~d}$ \\
\hline 9 & $\begin{array}{l}3.98 \mathrm{dd}(11.5,3.5) \\
3.78 \mathrm{~m}\end{array}$ & $66.5 \mathrm{t}$ & $3^{\prime}$ & & $148.4 \mathrm{~s}$ & 9 & & $164.6 \mathrm{~s}$ \\
\hline 10 & $3.37,3.32 \mathrm{~m}$ & $65.3 \mathrm{t}$ & $4^{\prime}$ & & $145.8 \mathrm{~s}$ & 10 & & $103.3 \mathrm{~s}$ \\
\hline 11 & $1.14 \mathrm{t}(7.0)$ & $15.6 \mathrm{q}$ & $5^{\prime}$ & $6.62 \mathrm{~d}(8.0)$ & $115.7 \mathrm{~d}$ & $1^{\prime}$ & & $136.3 \mathrm{~s}$ \\
\hline $1^{\prime}$ & & $132.7 \mathrm{~s}$ & $6^{\prime}$ & $6.52 \mathrm{dd}(8.0,2.0)$ & $123.1 \mathrm{~d}$ & $2^{\prime}$ & $6.62 \mathrm{~d}(2.0)$ & $129.9 \mathrm{~d}$ \\
\hline $2^{\prime}$ & $7.01 \mathrm{~d}(8.5)$ & $130.2 \mathrm{~d}$ & $\alpha$ & $4.13 \mathrm{t}(6.9)$ & $86.9 \mathrm{~d}$ & $3^{\prime}$ & & $154.7 \mathrm{~s}$ \\
\hline $3^{\prime}$ & $6.68 \mathrm{~d}(8.5)$ & $116.2 \mathrm{~d}$ & $\alpha^{\prime}$ & $\begin{array}{l}2.73 \mathrm{dd}(13.5,6.9) \\
2.96 \mathrm{dd}(13.5,6.9)\end{array}$ & $45.1 \mathrm{t}$ & $4^{\prime}$ & & $137.7 \mathrm{~s}$ \\
\hline $4^{\prime}$ & & $156.8 \mathrm{~s}$ & 3'-OMe & $3.70 \mathrm{~s}$ & $56.4 \mathrm{q}$ & $5^{\prime}$ & & $151.8 \mathrm{~s}$ \\
\hline $5^{\prime}$ & $6.68 \mathrm{~d}(8.5)$ & $116.2 \mathrm{~d}$ & 3-OMe & $3.75 \mathrm{~s}$ & $56.5 \mathrm{q}$ & $6^{\prime}$ & $6.61 \mathrm{~d}(2.0)$ & $108.2 \mathrm{~d}$ \\
\hline $6^{\prime}$ & $7.01 \mathrm{~d}(8.5)$ & $130.2 \mathrm{~d}$ & $\alpha-\mathrm{OMe}$ & $3.17 \mathrm{~s}$ & $56.7 \mathrm{q}$ & 3'-OMe & $3.83 \mathrm{~s}$ & $56.4 \mathrm{q}$ \\
\hline $7^{\prime}$ & $2.79 \mathrm{t}(7.5)$ & $31.0 \mathrm{t}$ & & & & 4'-OMe & $3.77 \mathrm{~s}$ & $61.0 \mathrm{q}$ \\
\hline $8^{\prime}$ & $2.59 \mathrm{t}(7.5)$ & $37.1 \mathrm{t}$ & & & & & & \\
\hline $9^{\prime}$ & & $174.6 \mathrm{~s}$ & & & & & & \\
\hline 3-OMe & $3.81 \mathrm{~s}$ & $56.3 \mathrm{q}$ & & & & & & \\
\hline
\end{tabular}

${ }^{\mathrm{a} 1} \mathrm{H}$ and ${ }^{13} \mathrm{C}$ NMR data were recorded at $500 \mathrm{MHz}$ and $125 \mathrm{MHz}$, respectively

${ }^{\mathrm{b} 1} \mathrm{H}$ and ${ }^{13} \mathrm{C}$ NMR data were recorded at $600 \mathrm{MHz}$ and $150 \mathrm{MHz}$, respectively

potent chain breaking action and they may contribute directly to the anti-oxidative activity [33]. The DPPH radical scavenging assay is one of the most common and relatively quick methods used for evaluating antioxidant activity. Compounds that can donate a hydrogen atom to the DPPH radical, and then gives rise to the reduced form of DPPH which will be considered as potential antioxidant agents. All compounds were evaluated for their DPPH radical scavenging activities. The present results (Table 2) exhibited that the majority of the phenolic compounds ( $\mathbf{1}$, 4-8, 13 and 14) showed significant activities with scavenging capacities ranging from 89.411 to $94.278 \%$ at $100 \mu \mathrm{g} /$ $\mathrm{mL}$.

On the other hand, tyrosinase is the copper containing enzyme and plays a critical role in controlling melanin biosynthesis pathway in melanocytes [34]. Therefore, tyrosinase inhibitors became important constituents of cosmetics or as medicinal products for hyperpigmentation and developing skin whitening agents. In the present study, all the isolates were evaluated for their tyrosinase inhibitory activity (Table 2). Kojic acid, a purported skin-lightening agent, was used as a positive control. 3,5,3'-hydroxybibenzyl (10) revealed a significant inhibitory activity with an $\mathrm{IC}_{50}$ value of $37.904 \mu \mathrm{g} / \mathrm{mL}$. Aphyllals C (11) showed moderate inhibition $\left(\mathrm{IC}_{50}, 152.56 \mu \mathrm{g} / \mathrm{mL}\right)$. All remaining compounds were inactive at concentrations up to $200 \mu \mathrm{g} / \mathrm{mL}$. In this study, it can be concluded that compounds $\mathbf{1 0}$ and $\mathbf{1 1}$ can be potential candidate for the treatment of melanin biosynthesis related skin diseases.

Considering that this species medicinally used for skin aging, since, collagen is critical for skin strength and elasticity, and its degradation leads to wrinkles that accompany aging [35]. Hence, all the compounds were also purposely evaluated for their effects on collagen production in HDFa. The results (Table 2) showed that compound 9 significant stimulation $\mathrm{HDFa}$ collagen production activity $\left(\mathrm{EC}_{50} 3.182 \mu \mathrm{g} / \mathrm{mL}\right)$. Compounds 6 and 7 showed weaker activities, with collagen production of $33.062 \%$ and $29.157 \%$ at $10 \mu \mathrm{g} / \mathrm{mL}$, respectively. The present results not only supported the ethnopharmacological usage of $D$. loddigesii but also provided a reliable structure template 
Table 2 Antioxidant, tyrosinase inhibitory and collagen production activities of compounds 1-14

\begin{tabular}{|c|c|c|c|c|c|}
\hline Compound & $\begin{array}{l}\text { DPPH radical scavenging } \\
\% \text { (at } 100 \mu \mathrm{g} / \mathrm{mL} \text { ) }\end{array}$ & $\begin{array}{l}\text { Tyrosinase inhibition \% } \\
\text { (at } 100 \mu \mathrm{g} / \mathrm{mL} \text { ) }\end{array}$ & $\begin{array}{l}\text { Tyrosinase inhibition } \\
\mathrm{IC}_{50}(\mu \mathrm{g} / \mathrm{mL})\end{array}$ & $\begin{array}{l}\text { Collagen production } \% \\
\text { (at } 10 \mu \mathrm{g} / \mathrm{mL} \text { ) }\end{array}$ & $\begin{array}{l}\text { Collagen } \\
\text { production } \mathrm{EC}_{50} \\
\mu \mathrm{g} / \mathrm{mL}\end{array}$ \\
\hline 1 & 91.435 & 31.421 & NA & -13.987 & NA \\
\hline 2 & 35.276 & -12.888 & NA & -3.515 & NA \\
\hline 3 & 13.322 & 5.432 & NA & 22.974 & NA \\
\hline 4 & 89.411 & 3.076 & NA & 22.974 & NA \\
\hline 5 & 92.912 & 1.767 & NA & 12.747 & NA \\
\hline 6 & 93.681 & 12.827 & NA & 33.062 & NA \\
\hline 7 & 93.391 & 13.358 & NA & 29.157 & NA \\
\hline 8 & 90.265 & 0.065 & NA & 24.552 & NA \\
\hline 9 & 26.644 & -2.880 & NA & 78.920 & 3.182 \\
\hline 10 & 33.903 & 75.360 & 37.904 & 16.665 & NA \\
\hline 11 & 29.292 & 44.403 & 152.56 & 10.871 & NA \\
\hline 12 & 12.041 & 15.249 & NA & 14.527 & NA \\
\hline 13 & 91.204 & 23.822 & NA & 19.632 & NA \\
\hline 14 & 94.278 & 2.618 & NA & 16.834 & NA \\
\hline Trolox $^{\mathrm{a}}$ & 96.089 & & & & \\
\hline Kojic acid ${ }^{b}$ & & 57.395 & 8.023 & & \\
\hline TGF- $\beta^{\mathrm{c}}$ & & & & 66.290 & \\
\hline
\end{tabular}

$N A$ not active

${ }^{\text {a }}$ Positive control used for DPPH radical scavenging assay at the concentration of $25 \mu \mathrm{g} / \mathrm{mL}$

${ }^{b}$ Positive control used for anti-tyrosinase assay at the concentration of $10 \mu \mathrm{g} / \mathrm{mL}$

${ }^{\mathrm{c}}$ Positive control used for collagen production assay at the concentration of $0.01 \mu \mathrm{g} / \mathrm{mL}$

for developing collagen deficiency associated diseases such as burn and ulcer.

\section{Experimental}

\subsection{General Experimental Procedures}

Optical rotation was obtained on a JASCO P-1020 digital polarimeter (Horiba, Tokyo, Japan). UV spectra were measured using a Shimadzu UV-2401 PC spectrophotometer (Shimadzu, Kyoto, Japan). IR spectra were obtained on a Bruker Tensor 27 infrared spectrophotometer (Bruker Optics $\mathrm{GmbH}$, Ettlingen, Germany) with $\mathrm{KBr}$ pellets. Mass spectra were performed on an API QSTAR time-of-flight spectrometer (MDS Sciqaszex, Concord, Ontario, Canada) and LCMSIT-TOF (Shimadzu, Kyoto, Japan) spectrometer. NMR spectra were recorded on DRX-500 and Av III-600 instruments with TMS as the internal standard (Bruker, Bremerhaven, Germany). The chemical shifts were given in $\delta$ (ppm) with reference to the solvent signal. Column chromatography was performed on silica gel (200-300 and 300-400 mesh, Qingdao Marine Chemical Inc., Qingdao, China), Lichroprep RP-18 gel (40-63 $\mu \mathrm{m}$, Merck, Darmstadt, Germany), MCI gel CHP-20P (75-150 $\mu \mathrm{m}$, Mitsubishi Chemical Corp.,
Tokyo, Japan), sephadex LH-20 (20-150 $\mu \mathrm{m}$, Amersham Biosciences, Uppsala, Sweden), and YMC*GEL ODS-AHG $(50 \mu \mathrm{m}$, YMC Co. Ltd. Japan). Fractions were monitored by TLC, and spots were visualized by UV light and sprayed with $10 \% \mathrm{H}_{2} \mathrm{SO}_{4}$ in EtOH, followed by heating. 1,1-diphenyl-2-picrylhydrazyl (DPPH), Trolox, mushroom tyrosinase, L-Dopa, and Kojic acid were purchased from Sigma (USA); Transforming growth factor beta (TGF- $\beta$ ) was obtained from Peprotech (USA); Growth media DMEM (high glucose w/L-glut), Hank's balanced salt solution, fetal bovine serum were purchased from HyClone (USA); Procollagen peptide ELISA kit was obtained from TaKaRa (Japan). All other chemicals and solvents were of analytical grade.

\subsection{Plant Material}

The stems of $D$. loddigesii were collected in September 2014 from Wenshan City, Yunnan Province, People's Republic of China and identified by Professor Hong Yu (Yunnan University, Kunming, People's Republic of China). The voucher specimen (No. 20,140,829) has been deposited at the State key Laboratory of Phytochemistry and Plant Resource in West China, Kunming Institute of Botany, Chinese Academy of Sciences. 


\subsection{Extraction and Isolation}

The dried and powdered stems $(10.2 \mathrm{~kg})$ of $D$. loddigesii were extracted three times with $80 \%$ ethanol under room temperature and concentrated under reduced pressure. Then, the residue was suspended in $\mathrm{H}_{2} \mathrm{O}$ and partitioned with EtOAc to obtain the EtOAc fraction $(220 \mathrm{~g})$, which was subjected to silica gel column chromatography eluted with a gradient of petroleum ether/acetone (15:1 to 0:1) to afford 22 fractions (Fr.1-22). Fr.11 (6 g) was subjected to silica gel CC eluted with $\mathrm{CHCl}_{3} / \mathrm{MeOH}$ (300:1), then followed by MCI column $\left(\mathrm{MeOH} / \mathrm{H}_{2} \mathrm{O}\right.$ gradient, 60:40-95:5) and silica gel $\mathrm{CC}\left(\mathrm{CHCl}_{3} / \mathrm{MeOH}, 200: 1\right)$ to yield 12 (4 mg). Fr.13 (850 mg) was separated over a column of MCI (MeOH/ $\mathrm{H}_{2} \mathrm{O}, 60: 40$ to $\left.95: 5\right)$ to give five fractions (Fr.13.1-Fr.13.5). Fr.13.4 $(150 \mathrm{mg})$ afforded compounds $4(3 \mathrm{mg})$ and 5 $(5 \mathrm{mg})$ by HPLC preparation $\left(\mathrm{MeOH} / \mathrm{H}_{2} \mathrm{O}, 60: 40\right)$. Fr.16 $(19 \mathrm{~g})$ was chromatographed on silica gel column eluted with $\mathrm{CHCl}_{3} / \mathrm{MeOH}(100: 1$ to $20: 1)$ to afford 6 subfractions (Fr.16.1-Fr.16.6). Fr.16.4 (2.3 g) was applied MCI column eluted with $\mathrm{MeOH} / \mathrm{H}_{2} \mathrm{O}$ (50:50-100:0) and then further fractionated over a column of sephadex LH-20 (MeOH/ $\left.\mathrm{H}_{2} \mathrm{O}, 90: 10\right)$ to yield $\mathbf{7}(716 \mathrm{mg})$ and $\mathbf{1 3}(39 \mathrm{mg})$. By using the same conditions of Fr.16.4, Fr.16.6 (240 mg) afforded compound $9(7 \mathrm{mg})$. Fr.18 $(10 \mathrm{~g})$ was separated by silica gel $\mathrm{CC}\left(\mathrm{CHCl}_{3} / \mathrm{MeOH}, 100: 1-20: 1\right)$, then passed through MCI $\left(\mathrm{MeOH} / \mathrm{H}_{2} \mathrm{O}\right.$ gradient, 50:50-100:0) and sephadex LH-20 $\left(\mathrm{MeOH} / \mathrm{H}_{2} \mathrm{O}, 90: 10\right)$ columns to yield $\mathbf{3}(25 \mathrm{mg})$ and $\mathbf{1 1}$ (4 mg). Fr.19 (20 g) was subjected to MCI column eluted with $\mathrm{MeOH} / \mathrm{H}_{2} \mathrm{O}$ (30:70-100:0) to obtain seven fractions (Fr.19.1-Fr.19.7). Fr.19.5 (2.3 g) was separated by repeated silica gel column $\left(\mathrm{CHCl}_{3} / \mathrm{MeOH}, 30: 1\right)$ to afford $\mathbf{8}(15 \mathrm{mg})$ and $10(7 \mathrm{mg})$. Fr.19.6 (4.3 g) was fractionated on a column of silica gel $\left(\mathrm{CHCl}_{3} / \mathrm{MeOH}, 30: 1\right)$ to give 5 fractions (Fr.19.6.1- Fr.19.6.5). Fr.19.6.1 (1.2 g) was subjected to silica gel column $\left(\mathrm{CHCl}_{3} / \mathrm{MeOH}, 30: 1\right)$ and after purification by HPLC $\left(\mathrm{MeOH} / \mathrm{H}_{2} \mathrm{O}, 45: 55\right)$, providing $1(15 \mathrm{mg})$. Fr.19.6.3 $(540 \mathrm{mg})$ was applied to a column of sephadex LH-20 column eluted with $\mathrm{MeOH} / \mathrm{H}_{2} \mathrm{O}$ (90:10), and then further purified by semipreparative $\mathrm{HPLC}\left(\mathrm{MeOH} / \mathrm{H}_{2} \mathrm{O}\right.$, 45:55) to furnish $2(6 \mathrm{mg})$ and $\mathbf{6}(5 \mathrm{mg})$. Fr.20 (12 g) was applied to a MCI gel $\left(\mathrm{MeOH} / \mathrm{H}_{2} \mathrm{O}, 30: 70-100: 0\right)$ chromatographic step and then was subjected to silica gel $\mathrm{CC}\left(\mathrm{CHCl}_{3} /\right.$ $\mathrm{MeOH}, 30: 1)$ to give $\mathbf{1 4}(21 \mathrm{mg})$.

threo-7-O-Ethyl-9-O-(4-hydroxyphenyl)propionyl-guaiacylglycerol (1): white solid; $[\alpha]_{\mathrm{D}}^{26}-3.72(c 0.51, \mathrm{MeOH})$; $\mathrm{UV}(\mathrm{MeOH}) \lambda_{\max }(\log \varepsilon) 203$ (4.53), 225 (4.17), 280 (3.66) $\mathrm{nm}$; IR (KBr) $\nu_{\max } 3426,1727,1516,829 \mathrm{~cm}^{-1} ;{ }^{1} \mathrm{H}$ and ${ }^{13} \mathrm{C}$ NMR $\left(\mathrm{CD}_{3} \mathrm{OD}\right)$, see Table 1 ; ESIMS $m / z 389[\mathrm{M}-\mathrm{H}]^{-}$, HRESIMS $\mathrm{m} / \mathrm{z} 389.1602[\mathrm{M}-\mathrm{H}]^{-}$(calcd. for $\mathrm{C}_{21} \mathrm{H}_{25} \mathrm{O}_{7}$, 389.1606).

(R)-4,5,4'-Trihydroxy-3,3', $\alpha$-trimethoxybibenzyl (2): white amorphous powder; $[\alpha]_{\mathrm{D}}^{26}-12.46(c 1.07, \mathrm{MeOH})$;
$\mathrm{UV}(\mathrm{MeOH}) \lambda_{\max }(\log \varepsilon) 204$ (4.59), 286 (3.75) nm; IR (KBr) $\nu_{\max } 3418,1607,1517,1455,1434,796 \mathrm{~cm}^{-1} ;{ }^{1} \mathrm{H}$ and ${ }^{13} \mathrm{C}$ NMR $\left(\mathrm{CD}_{3} \mathrm{OD}\right)$, see Table 1; ESIMS $\mathrm{m} / z 319$ $[\mathrm{M}-\mathrm{H}]^{-}$, HRESIMS $\mathrm{m} / z 319.1180[\mathrm{M}-\mathrm{H}]^{-}$(calcd. for $\left.\mathrm{C}_{17} \mathrm{H}_{19} \mathrm{O}_{6}, 319.1187\right)$.

(2S)-5,7,3'-Trihydroxy-6,4,5-trimethoxyflavone (3): yellow amorphous powder; $[\alpha]_{\mathrm{D}}^{26}-46.64(c 0.46, \mathrm{MeOH})$; $\mathrm{UV}(\mathrm{MeOH}) \lambda_{\max }(\log \varepsilon) 206$ (4.70), 294 (4.17) nm; IR (KBr) $\nu_{\max } 3335,2940,1641,1514,1462,1345,1434$, 1182, 1091, 998, $833 \mathrm{~cm}^{-1} ;{ }^{1} \mathrm{H}$ and ${ }^{13} \mathrm{C}$ NMR $\left(\mathrm{CD}_{3} \mathrm{OD}\right)$, see Table 1; ESIMS $\mathrm{m} / \mathrm{z} 331[\mathrm{M}-\mathrm{H}]^{-}$, HRESIMS $\mathrm{m} / \mathrm{z}$ $331.0819[\mathrm{M}-\mathrm{H}]^{-}\left(\right.$calcd. for $\left.\mathrm{C}_{17} \mathrm{H}_{15} \mathrm{O}_{7}, 331.0823\right)$.

\subsection{DPPH Radical Scavenging Activity Assay}

The free radical scavenging activity assay was carried out according to previous method [36] with some modifications. Briefly, $30 \mu \mathrm{L}$ samples $(1000 \mu \mathrm{g} / \mathrm{mL}$, dissolved in ethanol) and Trolox (1 $\mathrm{mM})$ were added to $270 \mu \mathrm{L}$ DPPH solution $(100 \mu \mathrm{M}$, dissolved in methanol), respectively. The reaction proceeded for $1 \mathrm{~h}$ at $37^{\circ} \mathrm{C}$ on a 96-well microplate. The absorbance was then read at $515 \mathrm{~nm}$ and percentage of total radical scavenging activity was calculated using the following formula: inhibition $\%=\left[\left(\mathrm{A}_{0}-\mathrm{A}_{1}\right) / \mathrm{A}_{0}\right] \times 100 \%$, where $\mathrm{A}_{0}$ is the absorbance of the DPPH without samples (control reaction) and $A_{1}$ is the absorbance of DPPH incubated with the samples. All the tests were conducted in triplicate and Trolox was used as a positive control agent.

\subsection{Mushroom Tyrosinase Inhibitory Assay}

Tyrosinase activity inhibition was determined spectrophotometrically according to the method described previously [36] with some modifications. Briefly, different concentrations of test compounds were prepared in 10\% DMSO. Each of the sample solution $(20 \mu \mathrm{M})$ were mixed with L-Dopa $(1.25 \mathrm{mM})$, and diluted with $970 \mu \mathrm{L}$ of $0.05 \mathrm{mM}$ sodium phosphate buffer (PBS, pH 6.8) in the test tubes. The reaction was initiated by adding mushroom tyrosinase $(25 \mathrm{U} / \mathrm{mL})$. The reaction mixture was incubated for $5 \mathrm{~min}$ at room temperature. The amount of Dopachrome in the mixture was determined by the measurement of the absorbance of each well at $490 \mathrm{~nm}$. Kojic acid was used as positive control. The inhibitory percentage of tyrosinase was calculated according to the following equation: Percent inhibition $=\left[\left(\mathrm{A}_{0}-\mathrm{A}_{1}\right) / \mathrm{A}_{0}\right] \times 100 \%$, where $\mathrm{A}_{0}$ is the absorbance of the Dopachrome without test compounds (control reaction) and $\mathrm{A}_{1}$ is the absorbance of Dopachrome incubated with the test compounds. 


\subsection{Collagen Production by HDFa Assay}

The HDFa cell line was obtained from Cascade Biologics. HDFa cells were seeded in 96-well plates containing DMEM with $10 \%$ FBS under a humidified atmosphere of $5 \% \mathrm{CO}_{2}$ at $37{ }^{\circ} \mathrm{C}$. After $24 \mathrm{~h}$ of incubation, the cells were treated with the test samples for $72 \mathrm{~h}\left(37^{\circ} \mathrm{C}, 5 \% \mathrm{CO}_{2}\right)$. TGF- $\beta$ was used as the positive control. Media $(50 \mu \mathrm{L})$ was collected from each well, and froze at $-80{ }^{\circ} \mathrm{C}$ until it was assayed with procollagen peptide ELISA kit. The concentration of pro-collagen was obtained by measuring the absorbance at $450 \mathrm{~nm}$ on the microplate reader. Remove all media from cells and add $100 \mu \mathrm{L}$ diluted MTS reagent to each well. The reaction incubated for $40 \mathrm{~min}$ at $37^{\circ} \mathrm{C}$. The absorbance was measured at $490 \mathrm{~nm}$ with a microplate reader. The increase percentage of collagen I production was calculated according to the following equation: cell viability $(\%)=($ Mean $\mathrm{OD}_{490}$ sample/Mean $\mathrm{OD}_{490}$ control); increase of collagen production $\%=\left(\mathrm{A}_{1} / \mathrm{B} / \mathrm{A}_{0}-1\right) \times 100 \%$. Where $\mathrm{A}_{1}$ is the absorbance with the samples, $A_{0}$ is the absorbance without samples (control reaction), and $\mathrm{B}$ is cell viability.

Acknowledgements This project was supported financially by the Yunnan Provincial Science and Technology Department (Nos. 2017ZF00304, 2015HB093 and 2019HA001). Authors are grateful to the staff of the analytical group of the State Key Laboratory of Phytochemistry and Plant Resources in West China, Kunming Institute of Botany, Chinese Academy of Sciences, for measurements of all spectra.

\section{Compliance with Ethical Standards}

Conflict of interest No potential conflict of interest was reported by the authors in this manuscript.

Open Access This article is distributed under the terms of the Creative Commons Attribution 4.0 International License (http://creativeco mmons.org/licenses/by/4.0/), which permits unrestricted use, distribution, and reproduction in any medium, provided you give appropriate credit to the original author(s) and the source, provide a link to the Creative Commons license, and indicate if changes were made.

\section{References}

1. D. Yang, Z.Q. Cheng, L. Yang, B. Hou, J. Yang, X.N. Li, C.T. Zi, F.W. Dong, Z.H. Liu, J. Zhou, Z.T. Ding, J.M. Hu, J. Nat. Prod. 81, 227-235 (2018)

2. X.M. Zhou, C.J. Zheng, L.S. Gan, G.Y. Chen, X.P. Zhang, X.P. Song, G.N. Li, C.G. Sun, J. Nat. Prod. 79, 1791-1797 (2016)

3. T.B. He, Y.P. Huang, L. Yang, T.T. Liu, W.Y. Gong, X.J. Wang, J. Sheng, J.M. Hu, Int. J. Biol. Macromol. 83, 34-41 (2016)

4. Y. Hu, C. Zhang, X. Zhao, Y. Wang, D. Feng, M. Zhang, H. Xie, J. Nat. Prod. 79, 252-256 (2016)

5. W.W. Fan, F.Q. Xu, F.W. Dong, X.N. Li, Y. Li, Y.Q. Liu, J. Zhou, J.M. Hu, Nat. Prod. Bioprospect. 3, 89-92 (2013)

6. Y. Lin, F. Wang, L.J. Yang, Z. Chun, J.K. Bao, G.L. Zhang, Phytochemistry 95, 242-251 (2013)
7. M. Moretti, L. Cossignani, F. Messina, L. Dominici, M. Villarini, M. Curini, M.C. Marcotullio, Food Chem. 140, 660-665 (2013)

8. S. Charoenrungruang, P. Chanvorachote, B. Sritularak, V. Pongrakhananon, J. Nat. Prod. 77, 1359-1366 (2014)

9. C.C. Chen, L.G. Wu, F.N. Ko, C.M. Teng, J. Nat. Prod. 57, 1271$1274(1994)$

10. Y. Deng, M. Li, L.X. Chen, X.Q. Chen, J.H. Lu, J. Zhao, S.P. Li, Carbohyd. Polym. 180, 238-245 (2018)

11. R. Li, T. Liu, M. Liu, F. Chen, S. Liu, J. Yang, J. Agric. Food Chem. 65, 3665-3674 (2017)

12. Editorial Committee of Flora Republicae Popularis Sinicae, (Academic Press. Beijing 19, 104 (1999)

13. Y. Lu, M. Kuang, G.P. Hu, R.B. Wu, J. Wang, L. Liu, Y.C. Lin, Molecules 19, 8544-8555 (2014)

14. C. Zhang, S.J. Liu, L. Yang, M.Y. Yuan, J.Y. Li, B. Hou, H.M. Li, X.Z. Yang, C.C. Ding, J.M. Hu, Fitoterapia 122, 76-79 (2017)

15. D. Yang, L.Y. Liu, Z.Q. Cheng, F.Q. Xu, W.W. Fan, C.T. Zi, F.W. Dong, J. Zhou, Z.T. Ding, J.M. Hu, Fitoterapia 100, 11-18 (2015)

16. W.W. Fan, F.Q. Xu, F.W. Dong, X.N. Li, X.Y. Wei, J. Zhou, J.M. Hu, Tetrahedron Lett. 54, 1928-1930 (2013)

17. F.Q. Xu, F.C. Xu, B. Hou, W.W. Fan, C.T. Zi, Y. Li, F.W. Dong, Y.Q. Liu, J. Sheng, Z.L. Zuo, J.M. Hu, Bioorg. Med. Chem. Lett. 24, 5268-5273 (2014)

18. C.L. Chang, L.J. Zhang, R.Y. Chen, C.C. Wu, H.C. Huang, M.C. Roy, J.P. Huang, Y.C. Wu, Y.H. Kuo, Bioorg. Med. Chem. 18, 518-525 (2010)

19. J. Cai, C. Yang, T. Chen, L. Zhao, Nat. Prod. Res. Nat. Prod. Res. 32, 1600-1604 (2018)

20. Y. Li, C.L. Wang, Y.J. Wang, S.X. Guo, J.S. Yang, X.M. Chen, P.G. Xiao, Chem. Pharm. Bull. 57, 218-219 (2009)

21. C.L. Chang, G.J. Wang, L.J. Zhang, W.J. Tsai, R.Y. Chen, Y.C. Wu, Y.H. Kuo, Phytochemistry 71, 271-279 (2010)

22. K. Šmejkal, L. Grycová, R. Marek, F. Lemière, D. Jankovská, H. Forejtniková, J. Vančo, V. Suchý, J. Nat. Prod. 70, 1244-1248 (2007)

23. D. Slade, D. Ferreira, J.P.J. Marais, Phytochemistry 66, 21772215 (2005)

24. P.L. Majumder, S. Chatterjee, Phytochemistry 28, 1986-1988 (1989)

25. P.L. Majumder, R.C. Sen, Phytochemistry 26, 2121-2124 (1987)

26. B. Sritularak, N. Duangrak, K. Likhitwitayawuid, Z. Naturforsch. C 66, 205-208 (2011)

27. Y.W. Leong, C.C. Kang, L.J. Harrison, A.D. Powell, Phytochemistry 44, 157-165 (1996)

28. P.L. Majumder, S. Pal, Phytochemistry 32, 1561-1565 (1993)

29. C.F. Xie, H.Q. Yuan, J.B. Qu, J. Xing, B.B. Lue, X.N. Wang, M. Ji, H.X. Lou, Chem. Biodiversity 6, 1193-1201 (2009)

30. C.Q. Fan, W.M. Zhao, G.W. Qin, Chin. Chem. Lett. 11, 705-706 (2000)

31. Y. Tezuka, Y. Yoshida, T. Kikuchi, G.J. Xu, Chem. Pharm. Bull. 41, 1346-1349 (1993)

32. F.M.M. Darwish, M.G. Reinecke, Phytochemistry 62, 1179-1184 (2003)

33. O. Demirkiran, T. Sabudak, M. Ozturk, G. Topcu, J. Agric. Food Chem. 61, 12598-12603 (2013)

34. K.H. Lee, F.H.A. Aziz, A. Syahida, F. Abas, K. Shaari, D.A. Israf, N.H. Lajis, Eur. J. Med. Chem. 44, 3195-3200 (2009)

35. H.I. Choi, H.J. Kim, J.I. Park, E.H. Shin, D.W. Kim, S.S. Kim, Bioorg. Med. Chem. Lett. 19, 2079-2082 (2009)

36. T. Sabudak, O. Demirkiran, M. Ozturk, G. Topcu, Phytochemistry 96, 305-311 (2013) 


\section{Affiliations}

Rui-Jing Ma ${ }^{1,2} \cdot$ Liu Yang $^{1,3} \cdot$ Xue Bai $^{1} \cdot$ Jin-Yu Li ${ }^{1} \cdot$ Ming-Yan Yuan ${ }^{1,3} \cdot$ Ya-Qin Wang ${ }^{3} \cdot$ Yong Xie $^{3} \cdot$ Jiang-Miao Hu He $^{1,3}$. Jun Zhou'

$\triangle$ Jiang-Miao $\mathrm{Hu}$

hujiangmiao@mail.kib.ac.cn

1 State Key Laboratory of Phytochemistry and Plant

Resources in West China, Kunming Institute of Botany,

Chinese Academy of Sciences, Kunming 650201,

People's Republic of China
2 College of Pharmacy, Guilin Medical University, Guilin 541004, People's Republic of China

3 R \& D Center of Dr. Plant, Kunming Institute of Botany, Chinese Academy of Sciences, Kunming 650201, People's Republic of China 